\title{
Profile and Determinants of the Middle Classes in Ghana: Energy Use and Sustainable Consumption
}

\author{
Bernardin Senadza ${ }^{1}$, Babette Never ${ }^{2}$, Sascha Kuhn $^{2}$ \& Felix A. Asante \\ ${ }^{1}$ Department of Economics, University of Ghana, Accra, Ghana \\ ${ }^{2}$ German Development Institute (DIE), Bonn, Germany \\ ${ }^{3}$ Institute of Statistical, Social and Economic Research, University of Ghana, Accra, Ghana \\ Correspondence: Bernardin Senadza, Department of Economics, University of Ghana, Accra, Ghana. E-mail: \\ bsenadza@ug.edu.gh
}

Received: May 9, 2020

Accepted: June 26, $2020 \quad$ Online Published: October 12, 2020

doi:10.5539/jsd.v13n6p11

URL: https://doi.org/10.5539/jsd.v13n6p11

\begin{abstract}
High and sustained economic growth rates of the Ghanaian economy in the past two to three decades have been accompanied by a growing urban middle class. With a rapidly growing middle class, overall consumption is not only increasing but changing too. This paper analyses the asset ownership patterns among the Ghanaian middle class, and examines the effect of household wealth, environmental concern and environmental knowledge on carbon dioxide emissions emanating from energy use and transport based on urban household survey data collected in Accra, the capital city, in 2018. We find that middle class households consume a variety of energy intensive consumer goods, and the intensity of consumption increases with household wealth. Regression results reveal statistically significant relationship between household wealth and carbon emissions from energy and transport use. We also find that environmental knowledge has a statistically negative effect on carbon emissions from transport. The policy implications are discussed.
\end{abstract}

Keywords: middle class, carbon dioxide emissions, sustainable consumption, household wealth, environmental concern, environmental knowledge, Ghana.

\section{Introduction}

Although the contribution of developing economies to global greenhouse gas (GHG) emissions remains historically meagre, levels of energy consumption in emerging economies have grown steadily at the turn of the millennium (Murthy et al., 2006). Per capita income growth, population growth and rapid urbanisation in many cities of developing countries have led to more carbon-intensive consumption lifestyles (Belloumi and Alshehry, 2016; Elliott et al., 2014; Jones, 1991). This trend has occasioned renewed interest not only in the adverse environmental impacts of production systems, but also the consumption patterns of the growing middle classes in these countries. The middle class represents a wellspring of consumers with sufficient income levels to purchase and use energy-intensive products (de Koning et al., 2015; King et al., 2008; Schmidt, 2009).

Ghana, which became a lower-middle income country in 2010, began to witness positive growth in the early 1980 s following implementation of economic and structural reforms, after about a decade of economic stagnation. The positive growth continued into the 1990s and beyond, averaging more than 7 percent per annum since 2005 . This sustained growth has translated into increased per capita income. Ghana also recorded consistent declines in the incidence of poverty between 1991 and 2017. (Note 1) These positive economic gains have been accompanied by a growing middle class, particularly in the urban areas of the country. Growth incidence analyses show that consumption growth in Ghana over the past two decades have concentrated above the fourth decile of the income distribution (Cooke et al., 2016; Senadza, 2013). With a rapidly growing middle class, overall consumption is not only increasing but changing too. Ghana's gross domestic product (GDP) has been rebased (Note 2) twice between 2010 and 2018 to reflect the current size of the economy and structural changes in production and consumption.

A growing middle class is beneficial from a development point of view as it provides a solid foundation for economic progress by driving domestic consumption and demand. At the same time the lifestyle or consumption choices of the middle class have implications for carbon dioxide (CO2) emissions and the environment generally. While the pursuit of strategies to reduce GHG emissions in industry have gained some attention, albeit Ghana's 
contribution to global GHG emissions is meagre by international standards (Benefoh and Ackom, 2016), not much has been done in the area of households' consumption lifestyles in the overall emissions dialogue. Households directly and indirectly contribute to rising $\mathrm{CO} 2$ emissions from the consumption of various goods and services (Serino and Klasen, 2015). The consumption choices of households can therefore play an important role in determining current and future volumes of GHG emissions (Girod and de Haan, 2010). Zhang (2011) argues that a sound financial environment, for example, provides consumers with the power to make big-ticket purchases such as automobiles and household appliances, which increases the rate of emissions. With a growing middle class made possible by rising per capita incomes, consumption patterns are likely to change towards more carbon intensive lifestyles. At the same time the theory of planned behaviour (Ajzen, 1985) posits that strong environmental values may influence attitudes, which in turn may lead to proenvironmental behaviour. Thus, if middle class households have strong environmental values, they may lead lifestyles that could moderate levels of carbon consumption. It is therefore imperative to identify opportunities for sustainable consumption to mitigate possible negative effects of the new consumption trends occasioned by the growing middle class in a developing country like Ghana. This would necessitate understanding the middle class, their lifestyles and consumption patterns. Key questions posed by this paper are: What are the socio-demographic characteristics of the middle class in Ghana? What kind of household assets do they own? To what extent do household wealth and environmental values influence their carbon consumption levels? While there is a dearth of studies on the carbon consumption patterns of middle class households in Ghana, existing research in developing countries have predominantly focused on the use of macro data and input-output tables (Wiedenhofer et al. 2016; Zhang 2017; Serino \& Klasen 2015). The novelty of our paper is to examine the middle class using micro level data collected on urban households in the Greater Accra region of Ghana. The objectives of the paper are two-fold. First, we analyse the patterns of asset ownership among the middle class. Second, we examine the effect of household wealth, environmental concern and environmental knowledge on $\mathrm{CO} 2$ emissions emanating from energy (electricity) consumption and transport use.

The rest of the paper is structured as follows. The next section explores the definition of the middle class and discusses correlates of carbon emissions at the household level. Section 3 discusses the materials and methods. Descriptive insights of the middle class, focusing on asset ownership patterns is discussed in section 4. Section 5 presents empirical results of correlates of energy (electricity) and transport consumption. Section 6 concludes.

\section{Literature Review}

\subsection{Defining the Middle Class}

There is no universally agreed definition of the middle class (Kharas, 2010; Pressman, 2010). From the social sciences perspective, a variety of definitions exist, ranging from an entirely subjective set of aspirations to a highly specific measure of household income (Reeves et al., 2018). Sociologists would typically emphasize education or occupational status while philosophers and anthropologists would broadly angle their propositions on culture, education and power (Reeves et al., 2018). In economics, income and/or wealth readily feature as definitional indices. Income-based definitions are widespread in the literature, albeit the absence of a consensus on the exact lower and upper bounds separating the middle class from the other social classes (Eisenhauer, 2008). There is, however, an apparent correlation of income with the other social class trappings, such as level of education, economic security, and consumer preferences (Leo et al., 2016).

Income-based conceptualisations of the middle class have typically relied on absolute purchasing power, the range of the income distribution, distance from the mean income or distance from the poverty line (Reeves et al., 2018). The middle class may be defined in absolute terms (Banerjee and Duflo, 2008; Kharas, 2010; Ravallion, 2009), where a fixed band is used for all countries, or in relative terms by examining the middle income range of each country. Kharas (2017), for instance, defines the middle class as those households with per capita incomes between $\$ 10$ and $\$ 100$ per person per day, in 2005 purchasing power parity (PPP) terms. Absolute income definitions provide a platform for cross-country comparisons. Relative definitions (Easterly, 2001; Palma, 2011) are able to capture regional differences more adequately, in the same vein as income polarization concepts (Foster and Wolfson, 2010). Gornick and Jäntti (2014), assert that the middle class could be described accurately as those households that fall in the middle of the income distribution, while Wolff (2017) proposes the middle three quintiles of the wealth distribution.

Despite its simplicity and appeal, the complex livelihood systems and plausible incidence of data collection errors and systematic measurement errors in developing countries often renders income data unreliable for robust analyses. (Note 3) Other measures of the middle class, featuring asset status and consumption capacity have been suggested (Brandi and Buege, 2014; Corral et al., 2015; Shimeles and Ncube, 2015). Beside the popular numerical 
measures are also the social and behavioural criteria, which are sometimes combined with numerical measures. In this definitional quest, understanding the drivers of the consumption decisions and behaviours of the middle class is key, evidenced on establishing who they are (self-awareness, and fundamental values or interests), what they have (income and assets), and what they do (individual attitudes and consumption behaviours) (CFAO, 2015). The novelty of our paper lies in how we defined the middle class. We employ a multi-dimensional empirical definition that combines an asset-based approach with information on household expenditures, in close resemblance to previous studies in Africa (CFAO, 2015). (Note 4)

\subsection{Correlates of Household Level Carbon Emissions}

Households' carbon emissions emanate from various sources including energy (appliance) use, transport, housing, etc. A plethora of studies on the drivers of household carbon consumption exist in developed countries (Baiocchi et al., 2010). More recently there has been studies on large middle income countries, including China and India. Household wealth (or income) is an important correlate of carbon footprints (Wiedenhofer et al., 2018). The direction of impact, however, is mixed. Ahmad et al., (2015), Qu et al., (2015), Serino and Klasen (2015), Xu et al., (2015), show that $\mathrm{CO}_{2}$ emissions tend to increase with household wealth. On the contrary, Wu et al., (2012) find that as income levels rise, households tend to explore more efficient energy sources. Romanos et al., (2014) observe that consumption by lower income households in New Zealand was more emissions intensive per dollar of expenditure than high income households, which corroborates Creedy and Sleeman (2006), and Grainger and Kolstad (2010).

Studies, in social psychology in particular, have noted individuals' proenvironmental behaviour to be influenced by their environmental values and knowledge. Therefore, higher environmental concern or knowledge may be associated with more environmentally friendly behaviour as implied by the theory of planned behaviour (Ajzen, 1985). While empirical evidence is mixed (Geng et al., 2017; Frederiks et al., 2015), especially regarding energy consumption (Paco and Lavrador, 2017), Haron et al., (2005), observe that high environmental knowledge increases the likelihood of sustainable consumption. Mohiuddin et al., (2018) reveal that environmental knowledge and awareness have significant influences on consumers' favourable attitudes toward green vehicles. Proponents of a weak relationship between environmental values and proenvironmental action contend that behavioural intentions may not be equated to actual behaviour. In other words, there exists a gap between environmental concern and actions: value-action gap (Blake, 1999) or environmental knowledge and action: knowledge-action gap (Kollmuss and Agyeman, 2002).

Socio-demographic and locational factors, such as household size, education, and urban-rural location, are also important predictors of CO2 emissions (Qu et al., 2015; Xu, et al., 2015). Serino and Klasen (2015) and Wu et al. (2012) have shown that larger households contribute more to emissions than smaller households. However, household size can be a key factor in reducing per capita carbon emissions when income differences are controlled for (Wiedenhofer et al., 2018). Ahmad et al. (2015) observes that household size has a negative relationship with emissions in India, just as Qu et al. (2015) in China, thus emphasising the importance of economies of scale in household energy consumption. Baiocchi, et al. (2010) and Wu et al. (2012) posit that more educated households emit less CO2 compared to less educated households. On the contrary, Xu, et al. (2015) observes that where the head attains a high level of education $\mathrm{CO} 2$ emissions tend to be higher. Our paper adds to the burgeoning microlevel literature on carbon consumption patterns of the growing middle class in developing countries by examining the Ghana specific case of the correlates of $\mathrm{CO} 2$ emissions by middle class households in selected metropolitan districts in the Greater Accra region of Ghana.

\section{Materials and Methods}

\subsection{Study Area, Conceptualisation of the Middle Class and Sampling Procedure}

The study was conducted in the Greater Accra region of Ghana, which houses the capital city, Accra. Middle class households were surveyed in 10 urban metropolitan districts. Previous research has shown that middle classes live in urban and metropolitan areas (Albert et al. 2018). Given the arbitrariness of the definition of the middle class in the literature and the general unreliability of income data in developing countries, this paper adopted a combination of criteria that allows for a non-income based identification of the middle class in our sample. We developed eight screening questions and a point system on assets, expenditures and education level of the household head.

The eight screening questions are: house size, house materials, house quality, house ownership or rental, type of water connection in the dwelling, annual expenditures on education, expenditure on eating out in a proper restaurant (e.g. with air conditioning), level of education of the household head. Three answer categories with 0-2 points were given for each question; a range of 0-14 points was possible. We purposively set the threshold for being middle class at 4-12 point with the aim of covering a broad range of potential middle class households 
(oversampling), which could be further defined and possibly excluded from data analysis ex post. In each of the 10 districts, we targeted gated communities that required pre-registration of interviews. Gated communities tend to be favoured by middle class households for their security, comfort and social network opportunities to other middle class families (Hamidu, 2015). At least one neighbourhood in the same district of each of the gated communities was randomly selected to account for the variation within the district. From a random starting point, every $5^{\text {th }}$ household was sampled. A total of 876 households were surveyed. The resulting sample approximates a representation of the middle classes in the city of Accra; they were not meant to be representative of the city population. Also, the approximation of a representative sample size of middle classes in the capital city was given priority over the capture of variation within the country by adding more cities.

\subsection{Measurement and Description of Variables}

The survey collected information on household socio-demographics, education, asset ownership, energy spending, mode of transport for daily commute, and a number of other household level variables to enable analysis of the socio-demographic and asset profiles of the middle class. In the descriptive section, we present these variables. Below, we describe the construction of the variables employed in the econometric analysis of the correlates of household carbon consumption levels.

\subsubsection{Dependent Variables}

The paper focuses on two sources of carbon emissions: energy and transport. Household energy use is measured directly via household monthly electricity expenditure estimates obtained from the survey. (Note 5) This was converted to annual values by multiplying monthly electricity expenditures by a factor of 12 . Carbon emissions from transport, on the other hand, are measured by computing emissions from each mode of transportation used by the household on a regular basis in grams of $\mathrm{CO} 2$ per kilometre $\left(\mathrm{g} \mathrm{CO}_{2} / \mathrm{km}\right)$. Total household carbon emissions are obtained as the sum of emissions from each mode of transport used by the household. This approach has been applied in previous studies, for instance, Xu, et al. (2015). Carbon emission factors for each transport mode were not readily obtained for Ghana. Consequently, we adopted the carbon emission factors in a study on Peru's urban transport (MTC \& GIZ, 2015). (Note 6) Table 1 presents the carbon coefficients for the various modes of household transport. In previous studies the carbon emission factors for each mode of transport are multiplied by the daily distance travelled. However, information on daily commuting distances was not collected in our survey. As such, we obtain carbon emissions from transport per kilometre distance travelled and then sum over the various modes of transport reported for each household. This sum is annualized by multiplying by a factor of 365 .

Table 1. Transportation carbon emission factors

\begin{tabular}{lr}
\hline Mode of travel & $\begin{array}{r}\text { Coefficient } \\
(\mathrm{g} \mathrm{CO} 2 / \mathrm{km})\end{array}$ \\
\cline { 2 - 3 } Car & 251.00 \\
Bus & 1.36 \\
Trotro (minivan) & 847.00 \\
Taxi/ uber & 233.00 \\
Motor bike & 73.00 \\
Bicycle/ foot & 0.00 \\
\hline
\end{tabular}

Source: MTC \& GIZ (2015)

\subsubsection{Independent Variables}

We focus on three key independent variables, namely, household wealth, environmental concern and environmental knowledge, in addition to socio-demographic characteristics of households, which are to serve as controls.

Income, a measure of household wealth or socio-economic status (SES), is a key determinant of carbon footprints. As is typical of households in developing countries, reported incomes are often inaccurate and unreliable (Filmer and Pritchett, 2001). Household consumption expenditures, a preferred candidate, however, require an extensive questionnaire to collect, which was not possible in our study. Other measures of SES have been developed to capture living standards based on household ownership of various types of assets (Vyas and Kumaranayake, 2006). 
We adopt this approach to measuring household wealth. We construct a household wealth index based on principal component analysis (PCA) using household productive and non-productive assets (e.g. television, radio, computer, vehicle, etc.), housing amenities and characteristics (house size, house material, type of water connection to the dwelling, number of household members per room), and human assets (education level of the household head). We exclude energy-intensive assets to avoid the problem of collinearity, especially regarding energy spending. Our selected variables posted the least clumping and truncation when running a PCA. The PCA explains acceptable levels of variation in our data $(>20 \%)$. Following previous studies (Gwatkin et al., 2000; Vyas and Kumaranayake, 2006) we categories households into quintiles for descriptive analysis.

An environmental concern index is constructed as the mean of six questions on a 5-point Likert scale (Thogersen, Haugaard and Olesen, 2010). We compute environmental knowledge in a similar fashion using eight questions to more closely capture knowledge about energy and transport. The questions required "yes" or "no" responses. We compute the environmental knowledge variable as the sum of yes responses. We obtained indexes with good reliability (Cronbach's alpha between 0.50 and 0.70 ).

\section{Descriptive Insights on Asset Ownership by the Middle Class}

\subsection{Socio-Demographic Profile}

The middle class in Africa can be distinguished from lower and upper social strata by key socio-demographic characteristics such as being of middle age and having a good education level (CFAO, 2015). Table 2 presents socio-demographic indicators of households in our sample. The mean age of respondents (typically the head of household) is fairly even across wealth quintiles. The average number of household members and household members aged less than 18 years is comparable to the mean household sizes (4.6 and 1.8, respectively) of middle class households in Morocco, Cameroon, Cote d'Ivoire, Kenya and Nigeria (CFAO, 2015). The middle class are relatively well educated, as more than half of household heads have at least a bachelor's degree. The level of education is increasing in wealth. In terms of occupation, the middle class are engaged in various socioprofessional categories. Table 2 indicates that majority are employed as professionals in various fields (such as accountants, consultants, engineers, teachers, etc.), with this proportion increasing across wealth quintiles. 
Table 2. Socio-demographic characteristics of the middle class

\begin{tabular}{|c|c|c|c|c|c|c|}
\hline & \multirow[b]{2}{*}{ All } & \multicolumn{5}{|c|}{ Wealth quintile } \\
\hline & & Lowest & Second & Third & Fourth & Highest \\
\hline Age (mean years) & 45.3 & 47.5 & 46.4 & 45.0 & 42.8 & 44.9 \\
\hline Household members & 4.5 & 4.3 & 4.6 & 4.4 & 4.5 & 4.4 \\
\hline Household members under 18 years & 1.3 & 1.2 & 1.3 & 1.2 & 1.3 & 1.2 \\
\hline \multicolumn{7}{|l|}{$\operatorname{Sex}(\%)$} \\
\hline Male & 58.4 & 53.1 & 55.4 & 62.3 & 60.6 & 60.6 \\
\hline Female & 41.6 & 46.9 & 44.6 & 37.7 & 39.4 & 39.4 \\
\hline \multicolumn{7}{|l|}{ Highest education (\%) } \\
\hline None & 2.0 & 4.0 & 4.0 & 1.2 & 0.0 & 0.6 \\
\hline Basic & 11.4 & 29.1 & 14.3 & 10.0 & 3.4 & 2.3 \\
\hline Secondary & 31.6 & 44.6 & 45.1 & 29.9 & 18.4 & 17.1 \\
\hline Bachelor's degree & 30.7 & 17.7 & 27.4 & 35.1 & 37.7 & 34.3 \\
\hline Master's degree or higher & 24.4 & 4.6 & 9.1 & 24.1 & 39.4 & 45.7 \\
\hline \multicolumn{7}{|l|}{ Occupation (\%) } \\
\hline Unemployed & 13.1 & 16.6 & 13.7 & 14.3 & 10.3 & 10.9 \\
\hline Farming \& self-employed & 26.3 & 39.9 & 33.1 & 20.6 & 20.0 & 18.9 \\
\hline Professional & 56.1 & 39.4 & 49.1 & 58.9 & 65.7 & 67.4 \\
\hline Inactive (retirees \& students) & 4.5 & 5.1 & 4.0 & 6.3 & 4.0 & 2.9 \\
\hline Lived/worked overseas (\%) & 35.4 & 23.4 & 27.4 & 40.6 & 34.3 & 51.4 \\
\hline \multicolumn{7}{|l|}{ Of which (\%) } \\
\hline Europe \& North America & 57.1 & 38.7 & 55.6 & 58.2 & 63.5 & 62.1 \\
\hline Asia and Oceania & 11.6 & 13.6 & 3.7 & 13.4 & 9.5 & 15.9 \\
\hline Other African country & 31.3 & 47.7 & 40.7 & 28.4 & 27.0 & 22.0 \\
\hline Lives in gated community (\%) & 47.0 & 30.3 & 33.7 & 56.0 & 56.0 & 58.9 \\
\hline Environmental knowledge & 5.6 & 5.0 & 5.4 & 5.5 & 5.9 & 6.0 \\
\hline Environmental concern & 4.0 & 3.9 & 4.0 & 4.0 & 4.1 & 4.2 \\
\hline
\end{tabular}

Source: Survey data, 2018.

More than a third of respondents have lived and/or worked outside Ghana, predominantly in Europe and North America. Overseas experience may thus be a distinguishing feature of the Ghana middle class. Our data, however, does not show whether the Ghanaian diaspora moves into middle class only upon returning or whether most of these individuals have come from middle class families before leaving already. Nearly half of the households live in gated estate homes in their various neighbourhoods. This is more widespread among the upper 60 percent of households. The mean scores for environmental knowledge of 5.6 out of a maximum of 8 and environmental concern of 4 out of a maximum of 6 indicate a fairly high level, albeit self-reported, of environmental knowledge and concern among the middle class. 


\subsection{Asset Ownership}

Middle class households typically consume a variety of consumer goods, some of which are energy intensive and/or are of new technologies. Column 2 of Table 3 reports survey findings on ownership rates of appliances and means of transport by middle class households in urban Accra. We also report the variations across wealth quintiles. The most commonly owned household assets are television, fridge, fan and smartphone, where at least 95 percent of households reported owning such assets. Other household appliances that are quite popular among the middle class are laptop computer, freezers, microwave and rice cooker. Generally, ownership of the various types of assets is increasing in household wealth. These ownership patterns are comparable to the findings of CFAO (2015) for Morocco, Cameroon, Cote d'Ivoire, Kenya and Nigeria. Owning a means of transport, particularly, a vehicle is a key characteristic of the African middle class (CFAO, 2015). Table 3 shows that 64 percent of households own at least one car, which is higher than the average of 57 percent obtained for Morocco, Cameroon, Cote d'Ivoire, Kenya and Nigeria (CFAO, 2015). Ownership of vehicle is increasing in household wealth. The results also show a very low rate of motorbike ownership, while a little below a fifth of households owned a bicycle; and this is increasing in household wealth. Bicycles are rarely ridden by wealthy adults in Ghana but it is common to see children of wealthy households, especially in gated neighbourhoods or secluded residential areas riding bicycles in their communities.

Table 3. Asset ownership by middle class households

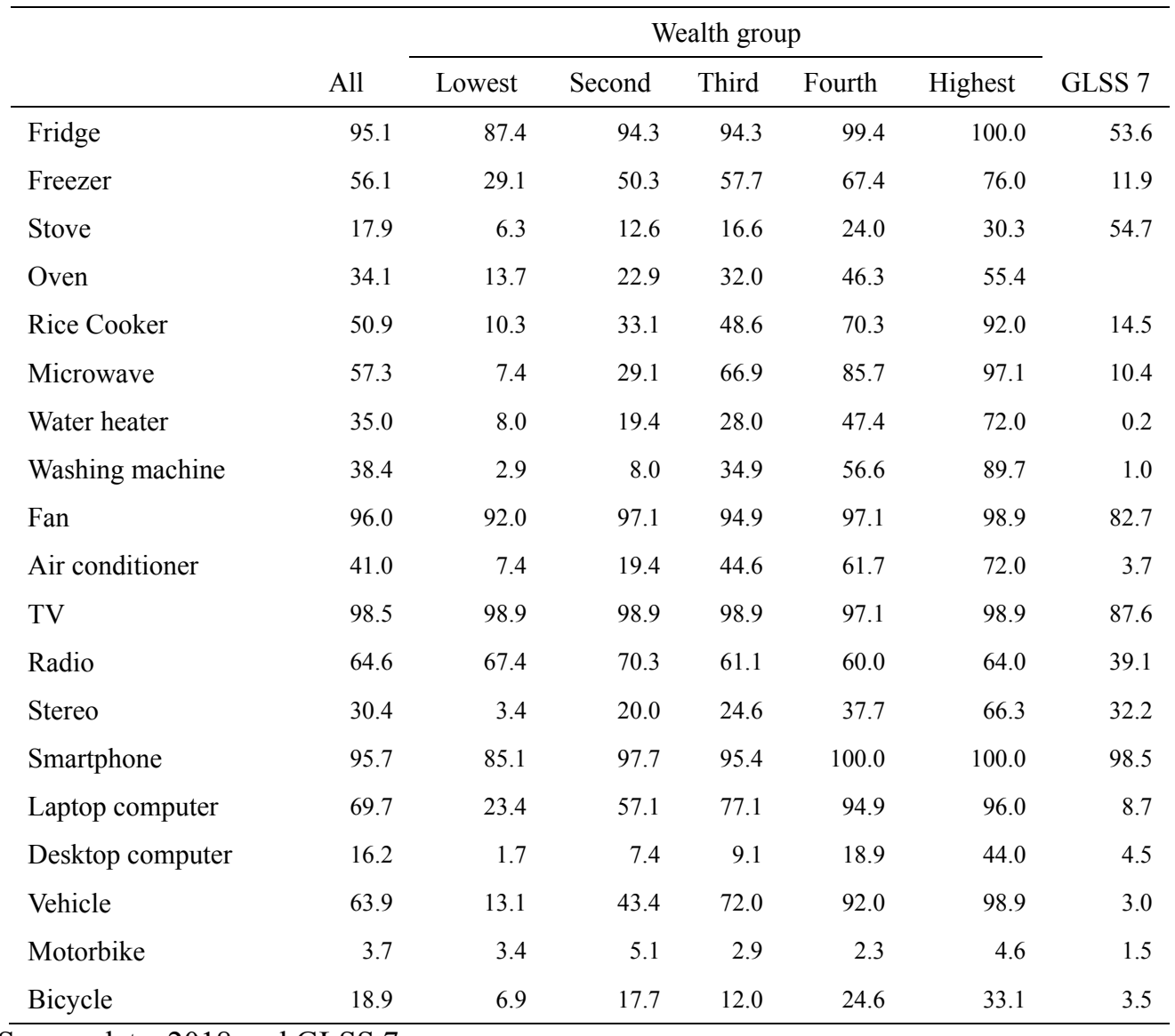

Source: Survey data, 2018 and GLSS 7

In Table 3, we also compare asset ownership from our survey to data from the seventh round of the Ghana Living Standards Survey (GLSS), a nationally representative household survey collected between 2016 and 2017. We define the middle class as households between the $50^{\text {th }}$ and $80^{\text {th }}$ percentile and restrict our comparator sample to the Greater Accra Metropolitan Area (GAMA). The GAMA region includes the ten districts sampled in our survey. The comparison is restricted to assets common to both datasets. Generally, the results show that asset ownership is higher in our sample than the comparator GLSS 7 sample for a majority of assets. The variations may arise from the differences in the sampling designs between the two 
surveys. The GLSS 7 followed a two-stage stratified sampling procedure with probability weights using national population and housing census data as the sampling frame. Our survey specifically targeted middle class households in the GAMA region. The GLSS, on the other hand, is random and does not exclude households based on living standards or assets as employed by our survey.

Typically, middle class households own more than just one of a particular type of asset as we found in our survey. We find in the data that generally for the majority of household assets, the quantities owned are increasing in household wealth. We present the particular case of vehicle ownership in Table 4. The wealth effects of the number and type of vehicles owned by the middle class is quite evident. There are variations in the types of vehicles owned in terms of wealth, with ownership of SUVs being more common among the richest 40 percent.

Table 4. Number and type of vehicles owned by middle class households (\%)

\begin{tabular}{lrrrrrr}
\hline & \multicolumn{7}{c}{ Wealth group } & \multirow{2}{*}{ All } \\
\cline { 2 - 5 } & Lowest & Second & Third & Fourth & Highest & \\
Number of vehicles & & & & & & \\
None & 86.9 & 56.6 & 28.0 & 8.0 & 1.1 & 36.1 \\
One & 12.0 & 34.3 & 46.9 & 48.6 & 37.1 & 35.8 \\
Two & 1.1 & 8.0 & 18.3 & 29.7 & 40.6 & 19.5 \\
3 or more & 0.0 & 1.1 & 6.9 & 13.7 & 21.1 & 8.6 \\
& & & & & & \\
\hline Type of vehicle & & & & & & \\
Small car & 56.5 & 34.2 & 33.3 & 24.2 & 24.9 & 29.2 \\
Mid-sized car & 39.1 & 53.9 & 54.0 & 70.2 & 61.8 & 60.5 \\
Minivan & 8.7 & 7.9 & 9.5 & 8.1 & 8.1 & 8.4 \\
SUV & 0.0 & 13.2 & 24.6 & 26.1 & 41.6 & 27.7 \\
Pick-up truck & 4.3 & 5.3 & 3.2 & 9.3 & 9.8 & 7.3 \\
Other car & 0.0 & 1.3 & 0.8 & 1.2 & 0.0 & 0.7 \\
\hline
\end{tabular}

Source: Survey data, 2018.

\section{Empirical Results}

\subsection{Results for Electricity Consumption}

Table 5 presents the results of the determinants of annual household electricity expenditures. We estimate an Ordinary Least Squares (OLS) model with robust standard errors, and a district-level Fixed Effects (FE) model. The FE model allows us to account for unobserved district-level heterogeneity that affects attitudes and behaviours towards energy consumption. We adopt a stepwise approach to the inclusion of explanatory variables. A baseline model is estimated, which includes as regressors household ownership of electricity intensive appliances and household wealth. Environmental knowledge and environmental concern variables are then added to the baseline model, before introduction of the controls variables.

The results of models (1) to (8) in Table 5 show a stable and robust relationship between the independent variables and annual household electricity expenditures, with the inclusion of additional explanatory variables. The Rsquared increases from the baseline model to the fully extended model. Discussion of findings focuses on the full model (models (7) and (8)). We find that household wealth is positively related to annual electricity expenditures. A unit increase in household wealth score raises annual electricity expenditure by 12 percent and 10 percent in the OLS and FE models, respectively. Our findings corroborate previous studies such as Ahmad et al., (2015), Baiocchi et al., (2010), Qu et al., (2015), Serino and Klasen (2015), Xu et al., (2015), which suggest that wealthier households consume larger amounts of electricity to provide for household services such as heating, cooking and entertainment. We do not however find a significant relationship between the level of environmental knowledge and environmental concern reported by the households on the one hand, and household annual electricity 
expenditures on the other.

Ownership of electricity-intensive appliances such as air conditioners, fridge and freezer are positively correlated with household electricity expenditures. The results also show statistically significant positive effect for household size. In terms of the educational attainment, the OLS regression estimates that households with the respondent having at least a master's degree expend more on electricity, significant only at the .10 level. Households living in gated communities on average spend about 10 percent more on electricity compared to households in non-gated communities. In the Ghanaian context, residency in gated communities may be viewed as a symbol of wealth and social standing among the middle class. As such, residents of gated communities may own energy-intensive electronic and electrical appliances to correspond to their social status. Respondents' migration history exerts a significant effect on household electricity expenditures (in the FE regressions in Column 8), albeit at the .10 level, while having previously lived or worked overseas results 8 percent more expenditure on electricity annually.

\subsection{Results for Transport Carbon Emissions}

Table 6 presents the determinants of carbon emissions from transportation. Similar to the analysis on electricity expenditures, we estimated both OLS and district-level FE models, and adopted a stepwise approach to inclusion of explanatory variables. The relationship between household wealth and carbon emissions from transportation is robust to the inclusion of additional explanatory variables from the base to the full model. The discussion of findings focuses on the extended regressions in Columns (7) and (8). The results show that carbon emission from transport is positively related to household wealth, which is significant at the .05 level, thus suggesting that wealthier households emit higher carbon from transportation relatively. This may be explained that the wealthier households are more inclined to purchase vehicles with high fuel consumption capacities, perhaps, in reflection of their social status. In addition, persons from upper middle-class households are more likely to use motorized means of transportation that rely on combustible fuels. Transportation use behaviour may therefore differ along the wealth distribution. We find that environmental knowledge has a statistically negative effect on carbon emissions from transport, whereas environmental concern has no effect.

We find a significant effect for sex, with households headed by a female emitting lower carbon per kilometre of distance travelled compared to males. The presence of the gender differences in carbon emissions from transport may reflect gender gaps in the ownership of automobiles as well as differences in mobility-based activities and choice of modes of commuting. There is an inverse relationship between age of head of household and transport carbon emissions. There does not appear to be a significant difference between education and household carbon emissions except for respondents with a bachelor's degree, albeit significant only at the 0.10 level. Education is an important determinant of labour market earnings. Thus, more educated persons on average may be wealthier with the ability to purchase private low occupancy vehicles. Further, the results show a positive relationship between the number of household members and transport-related carbon emissions, statistically significant at 5 percent. We do not find any statistically significant relationship between previous out-of-country migration experience and carbon emissions from transportation. Residency of a gated community is associated with lesser carbon emission scores from transport. 
Table 5. Determinants of household electricity expenditures

\begin{tabular}{|c|c|c|c|c|c|c|c|c|}
\hline & (1) & $\begin{array}{l}(2) \\
\mathrm{FF}\end{array}$ & (3) & (4) & $(5)$ & $\begin{array}{l}(6) \\
\mathrm{FF}\end{array}$ & (7) & (8) \\
\hline VARIABLES & OLS & FE & OLS & FE & OLS & FE & OLS & \\
\hline \multicolumn{9}{|l|}{ Asset ownership } \\
\hline \multirow[t]{2}{*}{ Electric oven } & 0.0444 & 0.0656 & 0.0471 & 0.0695 & 0.0351 & 0.0591 & 0.0372 & 0.0673 \\
\hline & $(0.0503)$ & $(0.0487)$ & $(0.0504)$ & $(0.0491)$ & $(0.0507)$ & $(0.0483)$ & $(0.0509)$ & $(0.0484)$ \\
\hline \multirow[t]{2}{*}{ Electric stove } & 0.0198 & 0.0245 & 0.0278 & 0.0331 & 0.0548 & 0.0575 & 0.0540 & 0.0572 \\
\hline & $(0.0556)$ & $(0.0584)$ & $(0.0559)$ & $(0.0588)$ & $(0.0553)$ & $(0.0579)$ & $(0.0552)$ & $(0.0578)$ \\
\hline \multirow[t]{2}{*}{ Air conditioner } & $0.4022 * * *$ & $0.3827 * * *$ & $0.4002^{* * *}$ & $0.3816^{* * *}$ & $0.3832 * * *$ & $0.3623 * * *$ & $0.3874 * * *$ & $0.3704 * * *$ \\
\hline & $(0.0485)$ & $(0.0506)$ & $(0.0487)$ & $(0.0508)$ & $(0.0479)$ & $(0.0504)$ & $(0.0479)$ & $(0.0504)$ \\
\hline \multirow[t]{2}{*}{ Freezer } & $0.2980^{* * *}$ & $0.2622 * * *$ & $0.2953 * * *$ & $0.2592 * * *$ & $0.2488^{* * *}$ & $0.2198^{* * *}$ & $0.2494 * * *$ & $0.2191^{* * *}$ \\
\hline & $(0.0466)$ & $(0.0468)$ & $(0.0467)$ & $(0.0472)$ & $(0.0461)$ & $(0.0473)$ & $(0.0462)$ & $(0.0472)$ \\
\hline \multirow[t]{2}{*}{ Fridge } & $0.2843^{* *}$ & $0.3035^{* * *}$ & $0.2889^{* *}$ & $0.3049 * * *$ & $0.3196^{* * *}$ & $0.3323^{* * *}$ & $0.3200^{* * *}$ & $0.3297 * * *$ \\
\hline & $(0.1143)$ & $(0.1042)$ & $(0.1153)$ & $(0.1046)$ & $(0.1143)$ & $(0.1026)$ & $(0.1149)$ & $(0.1024)$ \\
\hline \multirow[t]{2}{*}{ Wealth score } & $0.1297 * * *$ & $0.1130^{* * *}$ & $0.1299 * * *$ & $0.1084 * * *$ & $0.1174 * * *$ & $0.1013 * * *$ & $0.1185^{* * *}$ & $0.1033^{* * *}$ \\
\hline & $(0.0261)$ & $(0.0279)$ & $(0.0274)$ & $(0.0293)$ & $(0.0291)$ & $(0.0302)$ & $(0.0291)$ & $(0.0302)$ \\
\hline \multirow{2}{*}{$\begin{array}{l}\text { Environmental } \\
\text { knowledge }\end{array}$} & & & -0.0071 & 0.0036 & -0.0080 & 0.0038 & -0.0083 & 0.0038 \\
\hline & & & $(0.0160)$ & $(0.0154)$ & $(0.0162)$ & $(0.0156)$ & $(0.0162)$ & $(0.0155)$ \\
\hline \multirow[t]{2}{*}{ Environmental concern } & & & -0.0024 & 0.0104 & -0.0037 & 0.0121 & -0.0039 & 0.0150 \\
\hline & & & $(0.0375)$ & $(0.0384)$ & $(0.0375)$ & $(0.0380)$ & $(0.0374)$ & $(0.0379)$ \\
\hline \multirow[t]{2}{*}{ Female head } & & & & & 0.0555 & 0.0680 & 0.0552 & 0.0685 \\
\hline & & & & & $(0.0439)$ & $(0.0446)$ & $(0.0439)$ & $(0.0445)$ \\
\hline \multirow[t]{2}{*}{ Age } & & & & & 0.0000 & -0.0005 & 0.0000 & -0.0005 \\
\hline & & & & & $(0.0016)$ & $(0.0016)$ & $(0.0016)$ & $(0.0016)$ \\
\hline \multirow[t]{2}{*}{ Worked overseas } & & & & & 0.0668 & 0.0784 & 0.0674 & $0.0808^{*}$ \\
\hline & & & & & $(0.0487)$ & $(0.0480)$ & $(0.0487)$ & $(0.0479)$ \\
\hline \multicolumn{9}{|l|}{$\begin{array}{l}\text { Education (Ref. }=\text { No } \\
\text { education) }\end{array}$} \\
\hline \multirow[t]{2}{*}{ Basic education } & & & & & 0.1714 & 0.1474 & 0.1732 & 0.1490 \\
\hline & & & & & $(0.1428)$ & $(0.1659)$ & $(0.1427)$ & $(0.1655)$ \\
\hline \multirow[t]{2}{*}{ Secondary education } & & & & & 0.1791 & 0.1336 & 0.1840 & 0.1410 \\
\hline & & & & & $(0.1348)$ & $(0.1617)$ & $(0.1343)$ & $(0.1614)$ \\
\hline \multirow[t]{2}{*}{ Bachelor's degree } & & & & & 0.2066 & 0.1468 & 0.2142 & 0.1625 \\
\hline & & & & & $(0.1389)$ & $(0.1657)$ & $(0.1387)$ & $(0.1656)$ \\
\hline \multirow{2}{*}{$\begin{array}{l}\text { Master's degree and } \\
\text { above }\end{array}$} & & & & & $0.2624^{*}$ & 0.2031 & $0.2743^{*}$ & 0.2302 \\
\hline & & & & & $(0.1427)$ & $(0.1691)$ & $(0.1428)$ & $(0.1692)$ \\
\hline \multirow[t]{2}{*}{ Household members } & & & & & $0.0701 * * *$ & $0.0681 * * *$ & $0.0691 * * *$ & $0.0659 * * *$ \\
\hline & & & & & $(0.0106)$ & $(0.0102)$ & $(0.0107)$ & $(0.0102)$ \\
\hline \multirow[t]{2}{*}{ Gated community } & & & & & & & 0.0378 & $0.0968^{* *}$ \\
\hline & & & & & & & $(0.0459)$ & $(0.0469)$ \\
\hline \multirow[t]{2}{*}{ Constant } & $6.7811^{* * *}$ & $6.7826^{* * *}$ & $6.8078^{* * *}$ & $6.7072 * * *$ & $6.2644 * * *$ & $6.2140 * * *$ & $6.2391 * * *$ & $6.1403 * * *$ \\
\hline & $(0.1217)$ & $(0.1106)$ & $(0.2014)$ & $(0.1997)$ & $(0.2654)$ & $(0.2646)$ & $(0.2667)$ & $(0.2664)$ \\
\hline Observations & 843 & 843 & 837 & 837 & 836 & 836 & 836 & 836 \\
\hline R-squared & 0.2662 & 0.2318 & 0.2668 & 0.2323 & 0.3098 & 0.2764 & 0.3104 & 0.2802 \\
\hline Number of districts & & 10 & & 10 & & 10 & & 10 \\
\hline
\end{tabular}

Robust standard errors in parentheses

$* * * \mathrm{p}<0.01,{ }^{* *} \mathrm{p}<0.05,{ }^{*} \mathrm{p}<0.1$ 
Table 6. Determinants of $\mathrm{CO}_{2}$ Emission from Transport

\begin{tabular}{|c|c|c|c|c|c|c|c|c|}
\hline & (1) & (2) & (3) & (4) & (5) & (6) & (7) & (8) \\
\hline VARIABLES & OLS & $\mathrm{FE}$ & OLS & $\mathrm{FE}$ & OLS & $\mathrm{FE}$ & OLS & $\mathrm{FE}$ \\
\hline \multirow[t]{2}{*}{ Wealth score } & $0.1486^{* * *}$ & $0.1452 * * *$ & $0.1590^{* * *}$ & $0.1544 * * *$ & $0.0855^{* *}$ & $0.0886^{* *}$ & $0.0768 * *$ & $0.0785 * *$ \\
\hline & $(0.0333)$ & $(0.0342)$ & $(0.0340)$ & $(0.0354)$ & $(0.0375)$ & $(0.0383)$ & $(0.0380)$ & $(0.0384)$ \\
\hline \multirow[t]{2}{*}{ Knowledge } & & & $-0.0391 *$ & -0.0291 & $-0.0569 * * *$ & $-0.0464 *$ & $-0.0560 * *$ & $-0.0462 *$ \\
\hline & & & $(0.0220)$ & $(0.0236)$ & $(0.0220)$ & $(0.0238)$ & $(0.0218)$ & $(0.0237)$ \\
\hline \multirow[t]{2}{*}{ Concern } & & & 0.0297 & 0.0195 & 0.0401 & 0.0345 & 0.0404 & 0.0292 \\
\hline & & & $(0.0554)$ & $(0.0600)$ & $(0.0544)$ & $(0.0590)$ & $(0.0546)$ & $(0.0589)$ \\
\hline \multirow[t]{2}{*}{ Female head } & & & & & $-0.1154 *$ & $-0.1308^{*}$ & $-0.1148^{*}$ & $-0.1326^{*}$ \\
\hline & & & & & $(0.0664)$ & $(0.0686)$ & $(0.0662)$ & $(0.0684)$ \\
\hline \multirow[t]{3}{*}{ Age } & & & & & $-0.0099 * * *$ & $-0.0109 * * *$ & - & - \\
\hline & & & & & & & $0.0099 * * *$ & $0.0108 * * *$ \\
\hline & & & & & $(0.0024)$ & $(0.0024)$ & $(0.0023)$ & $(0.0024)$ \\
\hline \multirow[t]{2}{*}{ Worked overseas } & & & & & 0.0042 & 0.0164 & 0.0026 & 0.0122 \\
\hline & & & & & $(0.0761)$ & $(0.0739)$ & $(0.0759)$ & $(0.0737)$ \\
\hline \multicolumn{9}{|l|}{ Educational (Ref. $=$} \\
\hline \multicolumn{9}{|l|}{ No education) } \\
\hline \multirow[t]{2}{*}{ Basic education } & & & & & -0.0249 & -0.0202 & -0.0320 & -0.0253 \\
\hline & & & & & $(0.3190)$ & $(0.2604)$ & $(0.3182)$ & $(0.2597)$ \\
\hline \multirow[t]{2}{*}{ Secondary education } & & & & & 0.1831 & 0.1573 & 0.1666 & 0.1430 \\
\hline & & & & & $(0.3120)$ & $(0.2529)$ & $(0.3116)$ & $(0.2523)$ \\
\hline \multirow[t]{2}{*}{ Bachelor's degree } & & & & & 0.5040 & $0.4638^{*}$ & 0.4772 & $0.4332 *$ \\
\hline & & & & & $(0.3171)$ & $(0.2587)$ & $(0.3164)$ & $(0.2583)$ \\
\hline \multirow{3}{*}{$\begin{array}{l}\text { Master's degree and } \\
\text { above }\end{array}$} & & & & & 0.3491 & 0.3039 & 0.3058 & 0.2494 \\
\hline & & & & & & & & \\
\hline & & & & & $(0.3169)$ & $(0.2635)$ & $(0.3164)$ & $(0.2637)$ \\
\hline \multirow[t]{2}{*}{ Household members } & & & & & $0.0301^{*}$ & $0.0278^{*}$ & $0.0329 * *$ & $0.0316^{* *}$ \\
\hline & & & & & $(0.0159)$ & $(0.0156)$ & $(0.0159)$ & $(0.0156)$ \\
\hline \multirow[t]{2}{*}{ Gated community } & & & & & & & $-0.1226^{*}$ & $-0.1732 * *$ \\
\hline & & & & & & & $(0.0687)$ & $(0.0720)$ \\
\hline \multirow[t]{2}{*}{ Constant } & -0.0000 & -0.0000 & 0.0997 & 0.0855 & 0.2239 & 0.2741 & 0.2936 & 0.3987 \\
\hline & $(0.0335)$ & $(0.0333)$ & $(0.2366)$ & $(0.2538)$ & $(0.4102)$ & $(0.3766)$ & $(0.4122)$ & $(0.3791)$ \\
\hline Observations & 875 & 875 & 874 & 874 & 873 & 873 & 873 & 873 \\
\hline R-squared & 0.0221 & 0.0205 & 0.0255 & 0.0224 & 0.0900 & 0.0885 & 0.0934 & 0.0946 \\
\hline Number of districts & & 10 & & 10 & & 10 & & 10 \\
\hline
\end{tabular}

Robust standard errors in parentheses

$* * * \mathrm{p}<0.01, * * \mathrm{p}<0.05, * \mathrm{p}<0.1$

\section{Conclusion and Implications for Policy}

Our results provide insights into the consumption patterns of the middle-class in an emerging economy such as 
Ghana, and lend credence to earlier findings that as household wealth increases carbon emissions from use of energy intensive appliances and transport would rise. These outcomes, however, in no way suggest reducing societal wealth/development or controlling the rising middle class in the quest to conserve energy. They only signal the need for policies and initiatives, geared towards fostering low-carbon lifestyle choices. Thus, initiatives aimed at improving household energy conservation behaviour through promotion of the use of energy efficient appliances among the middle class are recommended. Creating a market for more energy efficient products, better labelling, and stricter minimum requirements for technical devices, could moderate the intensity of energy use and reduce emissions. Public education and awareness campaigns alone are unlikely to yield desirable energy-reducing outcomes (as our results seem to suggest with the insensitivity of knowledge to household energy use/emissions). If sensitization campaigns are to be pursued, however, they should be executed in a way that guarantees deeper understanding and appreciation of the energy conservation agenda, using clear and easily understood approaches. Our findings further indicate the importance of household transportation modes in raising carbon emissions among the middle class. Particularly, middle classes in the higher wealth brackets tend to own vehicles with high fuel consumption capacities. The inefficient public transportation system in Ghana could be an explanation for to the high ownership rates of personal means of transport among many households in Ghana. Thus, instituting an efficient public transportation system and promotion of vehicles with low carbon emitting capacities is an imperative. Alternative transportation forms could be encouraged for use within inner urban areas with high traffic congestion to reduce the combustion of fossil fuels. These policies, however, may require substantial investments in urban infrastructure.

\section{References}

Ahmad, S., Baiocchi, G., \& Creutzig, F. (2015). $\mathrm{CO}_{2}$ emissions from direct energy use of urban households in India. Environmental science \& technology, 49(19), 11312-11320. https://doi.org/10.1021/es505814g

Ajzen, I. (1985). From intentions to actions: A theory of planned behavior. In Kuhl, J., \& Beckmann, J. (Eds.), Action control: From cognition to behavior (pp. 11-39). Springer-Verlag, Berlin, Heidelber, New York. https://doi.org/10.1007/978-3-642-69746-3_2

Albert, J. R. G., Santos, A. G. F., \& Vizmanos, J. F. V. (2018). Profile and Determinants of the Middle-Income Class in the Philippines. Discussion Paper 2018-20, Manila: Philippine Institute of Development Studies.

Baiocchi, G., Minx, J., \& Hubacek, K. (2010). The impact of social factors and consumer behavior on carbon dioxide emissions in the United Kingdom: A regression based on input- output and geo-demographic consumer segmentation data. Journal of Industrial Ecology, 14(1), 50-72. https://doi.org/10.1111/j.15309290.2009.00216.x

Banerjee, A., \& Duflo, E. (2008). What is middle class about the middle class around the world? Journal of Economic Perspectives, 22(2), 3-28. https://doi.org/10.1257/jep.22.2.3

Belloumi, M., \& Alshehry, A. (2016). The impact of urbanization on energy intensity in Saudi Arabia. Sustainability, 8(4), 1-17. https://doi.org/10.3390/su8040375

Benefoh, D. T., \& Ackom, E. (2016). Energy and low carbon development efforts in Ghana: Institutional arrangements, initiatives, challenges and the way forward. AIMS Energy, 4(3), 481-503. https://doi.org/10.3934/energy.2016.3.481

Blake, J. (1999). Overcoming the 'value-action gap' in environmental policy: Tensions between national policy and local experience. Local environment, 4(3), 257-278. https://doi.org/10.1080/13549839908725599

Brandi, C., \& Buege, M. (2014). A Cartography of the New Middle Classes in Developing and Emerging Countries. Discussion Paper 35, Bonn: German Development Institute.

CFAO. (2015). The Middle Classes in Africa: Realities and challenges. White Paper: Review of research on the middle class, a contested concept with multiple definitions, BearingPoint \& Ipsos. Retrieved January 25, 2019, from http://www.cfaogroup.com/en/news/cfao-survey-on-africa-s-middle-classes-paints-detailed-picture-ofnew-african-consumers_2/page/1

Cooke, E., Hague, S., \& McKay, A. (2016). The Ghana poverty and inequality report: Using the 6th Ghana living standards survey. UNICEF Ghana. Retrieved October 20, 2018, from http://www.unicef.org/ghana/resources.html

Corral, P., Molini, V., \& Oseni, G. (2015). No Condition is Permanent: Middle Class in Nigeria in the Last Decade. World Bank Policy Research Working Paper 7214. Washington, D.C.: World Bank. https://doi.org/10.1596/1813-9450-7214 
Creedy, J., \& Sleeman, C. (2006). Carbon taxation, prices and welfare in New Zealand. Ecological Economics, 57(3), 333-345. https://doi.org/10.1016/j.ecolecon.2005.04.015

de Haan, P. (2010). More or better? A model for changes in household greenhouse gas emissions due to higher income. Journal of Industrial Ecology, 14(1), 31-49. https://doi.org/10.1111/j.1530-9290.2009.00202.x

de Koning, J. I. J. C., Crul, M. R. M., Wever, R., \& Brezet, J. C. (2015). Sustainable consumption in Vietnam: an explorative study among the urban middle class. International Journal of Consumer Studies, 39(6), 608-618. https://doi.org/10.1111/ijcs.12235

Easterly, W. (2001). The middle class consensus and economic development. Journal of Economic Growth, 6(4), 317-335. https://doi.org/10.1023/A:1012786330095

Eisenhauer, J. (2008). An economic definition of the middle class. Forum for Social Economics, 37(2), 108-113. https://doi.org/10.1007/s12143-007-9009-y

Elliott, R. J., Sun, P., \& Zhu, T. (2014). Urbanization and energy intensity: a province-level study for China. Discussion Paper 14-05, Department of Economics, University of Birmingham.

Essel, D. (2016) Vehicle population and growth rate. Ministry of Transport, Republic of Ghana, Accra. Retrieved October 2, 2019, from https://wedocs.unep.org/bitstream/handle/20.500.11822/21481/Vehicle\%20Popultaion\%20and\%20Growth $\% 20$ Rate $\% 2$ C\%20Daniel $\% 20$ Essel $\% 2 \mathrm{C} \% 20$ Ministry\%20of\%20Transport $\% 20$ Ghana.pdf? sequence=1\&isA llowed $=\mathrm{y}$

Filmer, D., \& Pritchett, L. H. (2001). Estimating wealth effect without expenditure data - or tears: an application to educational enrollments in states of India. Demography, 38, 115-32. https://doi.org/10.1353/dem.2001.0003

Foster, J., \& Wolfson, M. (2010). Polarization and the decline of the middle class: Canada and the U.S. Journal of Economic Inequality, 8, 247-273. https://doi.org/10.1007/s10888-009-9122-7

Frederiks, E., Stenner, K., \& Hobman, E. (2015). The socio-demographic and psychological predictors of residential energy consumption. Energies, 8(1), 573-609. https://doi.org/10.3390/en8010573

Geng, D. Y., Liu, J. J., \& Zhu, Q. H. (2017). Motivating sustainable consumption among Chinese adolescents: an empirical examination. Journal of Cleaner Production, 141, 315-322. https://doi.org/10.1016/j.jclepro.2016.09.113

Girod, B., \& de Haan, P. (2010). More or better? A model for changes in household greenhouse gas emissions due to higher income. Journal of Industrial Ecology, 14(1), 31-49. https://doi.org/10.1111/j.15309290.2009.00202.x

Gornick, J. C., \& Jantti, M. (Eds.). (2014) Income Inequality: Economic disparities and the middle class in affluent countries. Stanford University Press, Stanford. https://doi.org/10.2307/j.ctvqsdkqx

Grainger, C. A., \& Kolstad, C. D. (2010). Who pays a price on carbon? Environmental and Resource Economics, 46(3), 359-376. https://doi.org/10.1007/s10640-010-9345-x

Gwatkin, D. R., Rustein, S., Johnson, K., Pande, R. P., \& Wagstaff, A. (2000). Socio-economic differences in health, nutrition, and population in Brazil. Country reports on HNP and poverty, Washington, DC, World Bank Group. Retrieved January 15, 2019, from http://documents.worldbank.org/curated/en/455461468015634905/Socioeconomic-differences-in-health-nutrition-and-population-in-Brazil

Hamidu, J. (2015). Are Ghanaian diaspora middle class? Linking middle class to political participation and stability in Ghana. Africa Development, 40(1), 139-157.

Haron, S. A., Paim, L., \& Yahaya, N. (2005). Towards sustainable consumption: an examination of environmental knowledge among Malaysians. International Journal of Consumer Studies, 29(5), 426-436. https://doi.org/10.1111/j.1470-6431.2005.00460.x

Jones, D. W. (1991). How urbanization affects energy-use in developing countries. Energy Policy, 19(7), 621-630. https://doi.org/10.1016/0301-4215(91)90094-5

Kharas, H. (2010). The emerging middle class in developing countries. Retrieved February 28, 2019, from Working Paper No. 285, Development Centre, Organisation for Economic Co-operation and Development, Paris. https://www.deepdyve.com/lp/the-organisation-for-economic-co-operation-and-development-oecd/theemerging-middle-class-in-developing-countries-3LsO3oEZ58 
Kharas, H. (2017). The unprecedented expansion of the global middle class: An update. Global Economy and Development Working Paper 100. Retrieved from https://www.brookings.edu/wpcontent/uploads/2017/02/global_20170228_global-middle-class.pdf

King, V. T., Nguyen, P. A., \& Nguyen, H. M. (2008). Professional middle class youth in post-reform Vietnam: Identity, continuity and change. Modern Asian Studies, 42, 783-813. https://doi.org/10.1017/S0026749X06002551

Kollmuss, A., \& Agyeman, J. (2002). Mind the Gap: Why do people act environmentally and what are the barriers to pro-environmental behaviour? Environmental Education Research, 8(3), 239-260. https://doi.org/10.1080/13504620220145401

Leo, Y., Fleury, E., Alvarez-Hamelin, J. I., Sarraute, C., \& Karsai, M. (2016). Socioeconomic correlations and stratification in social-communication networks. Journal of the Royal Society Interface, 13(125), 20160598. https://doi.org/10.1098/rsif.2016.0598

Ministry of Transport and Communications (MTC), and German Agency for International Cooperation (GIZ). (2015). TRANSPerú - Sustainable urban transport NAMA Peru. Eschborn: GIZ. Retrieved January 28, 2019, from www.transport-namas.org/

Mohiuddin, M., Al Mamun, A., Syed, F. A., Masud, M. M., \& Su, Z. (2018). Environmental knowledge, awareness, and business school students' intentions to purchase green vehicles in emerging countries. Sustainability, 10(5), 1534. https://doi.org/10.3390/su10051534

Murthy, N. S., Panda, M., \& Parikh, K. (2007). $\mathrm{CO}_{2}$ emission reduction strategies and economic development of India. Margin: The Journal of Applied Economic Research, 1(1), 85-118. https://doi.org/10.1177/097380100600100104

Paco, A., \& Lavrador, T. (2017). Environmental knowledge and attitudes and behaviours towards energy $\begin{array}{llll}\text { consumption. Journal of Environmental } & \text { Management, 197, }\end{array}$ https://doi.org/10.1016/j.jenvman.2017.03.100

Palma, J. (2011). Homogenuous middles vs heterogenuous tails and the end of the inverted U: It's all about the share of the rich. Development and Change, 42(1), 87-153. https://doi.org/10.1111/j.1467-7660.2011.01694.x

Pressman, S. (2010). The middle class throughout the world in the mid-2000s. Journal of Economic Issues, 44(1), 243-263. https://doi.org/10.2753/JEI0021-3624440112

Qu, J., Maraseni, T., Liu, L., Zhang, Z., \& Yusaf, T. (2015). A comparison of household carbon emission patterns of urban and rural China over the 17 year period (1995-2011). Energies, 8(9), 10537-10557. https://doi.org/10.3390/en80910537

Ravallion, M. (2009). The developing world's bulging (but vulnerable) “middle class". Policy Research Working Paper 4816, Washington, DC, World Bank Group. https://doi.org/10.1596/1813-9450-4816

Reeves, R. V., Guvot, K., \& Krause, E. (2018). Defining the middle class: cash, credentials, or culture? Brookings Institution Report. Retrieved January 20, 2019, from https://www.brookings.edu/research/defining-themiddle-class-cash-credentials-or-culture/

Romanos, C., Kerr, S., \& Will, C. (2014). Greenhouse gas emissions in New Zealand: A preliminary consumptionbased analysis. Motu Working Paper 14-05. Wellington, Motu Economic and Policy Research. https://doi.org/10.29310/wp.2014.05

Schmidt, V. H. (2009). The new middle classes: Globalizing lifestyles, consumerism and environmental concern. In Lange, H., \& Meier, L. (Eds.), The New Middle Classes: Globalizing Lifestyles, Consumerism and Environmental Concern (pp. 29-47). Springer, Berlin.

Senadza, B. (2013). An Assessment of the pro-poorness of Ghana's growth: 1991-2006. In Twerefou, D. K. et al (Eds.), Readings on Key Economic Issues in Ghana (pp. 33-56). Digibooks, Accra.

Serino, M. N. V., \& Klasen, S. (2015). Estimation and determinants of the Philippines' household carbon footprint. The Developing Economies, 53(1), 44-62. https://doi.org/10.1111/deve.12065

Shimeles, A., \& Ncube, M. (2015). The making of the middle-class in Africa: Evidence from DHS data. Journal of Development Studies, 51(2), 178-193. https://doi.org/10.1080/00220388.2014.968137

Thogersen, J., Haugaard, P., \& Olesen, A. (2010). Consumer responses to ecolabels. European Journal of Marketing, 44(11/12), 1787-1810. https://doi.org/10.1108/03090561011079882 
Vyas, S., \& Kumaranayake, L. (2006). Constructing socio-economic status indices: how to use principal components analysis. Health Policy Plan, 21(6), 459-68. https://doi.org/10.1093/heapol/czl029

Wiedenhofer, D., Guan, D., Liu, Z., Meng, J., Zhang, N., \& Wei, Y. (2016). Unequal household carbon footprints in China. Nature Climate Change, 7, 75-81. https://doi.org/10.1038/nclimate3165

Wiedenhofer, D., Smetschka, B., Akenji, L., Jalas, M., \& Haberl, H. (2018). Household time use, carbon footprints, and urban form: a review of the potential contributions of everyday living to the $1.5 \mathrm{C}$ climate target. Current opinion in environmental sustainability, 30, 7-17. https://doi.org/10.1016/j.cosust.2018.02.007

Wolff, E. N. (2017). Household wealth trends in the United States, 1962 to 2016: Has middle class wealth recovered? National Bureau of Economic Research Working Paper No. w24085. https://doi.org/10.3386/w24085

Wu, G., Liu, T., \& Tang, M. (2012). Analysis of household energy consumption and related $\mathrm{CO}_{2}$ emissions in the disregarded villages of Lijiang City, China. International Journal of Sustainable Development \& World Ecology, 19(6), 500-505. https://doi.org/10.1080/13504509.2012.701242

Xu, X., Tan, Y., Chen, S., Yang, G., \& Su, W. (2015). Urban household carbon emission and contributing factors in the Yangtze River Delta, China. PloS one, 10(4). https://doi.org/10.1371/journal.pone.0121604

Zhang, Y. J. (2011). The impact of financial development of carbon emissions: An empirical analysis in China. Energy Policy, 39(4), 2197-2203. https://doi.org/10.1016/j.enpol.2011.02.026

\section{Notes}

Note 1 . Based on a line of approximately US $\$ 2$ a day, poverty declined from $51.7 \%$ to $39.5 \%$ between 1991 and 1999. It declined further to $28.5 \%$ and $24.3 \%$ in 2006 and 2013, respectively, before registering a marginal decline of about 1 percentage point to reach $23.4 \%$ in 2017 .

Note 2. Rebasing an economy involves revising the methods and the base year used to calculate a country's GDP. The first rebasing of Ghana's GDP occurred in 2010 and that resulted in a 75\% increase in the country's GDP. In 2018, the Ghana Statistical Service again rebased the GDP which led to a $26 \%$ increase in the value of Ghana's GDP.

Note 3. For this reason consumption data is often preferred to income data in household analyses in developing countries (see Filmer and Pritchett, 2001).

Note 4. A detailed discussion of our definition of the middle class is in section 3.1.

Note 5 . We use energy expenditure instead of kilowatt hours consumed, which we could not obtain for the majority of households.

Note 6. Our assumption seems quite plausible as the estimated average age of vehicles in both countries is quite close. The estimated average age of vehicles in Peru is between 12 and 14 years (MTC \& GIZ, 2015), while Essel (2016) estimates Ghana's at 14.2 years.

\section{Copyrights}

Copyright for this article is retained by the author(s), with first publication rights granted to the journal.

This is an open-access article distributed under the terms and conditions of the Creative Commons Attribution license (http://creativecommons.org/licenses/by/4.0/). 